\title{
Catalyst Characterization
}

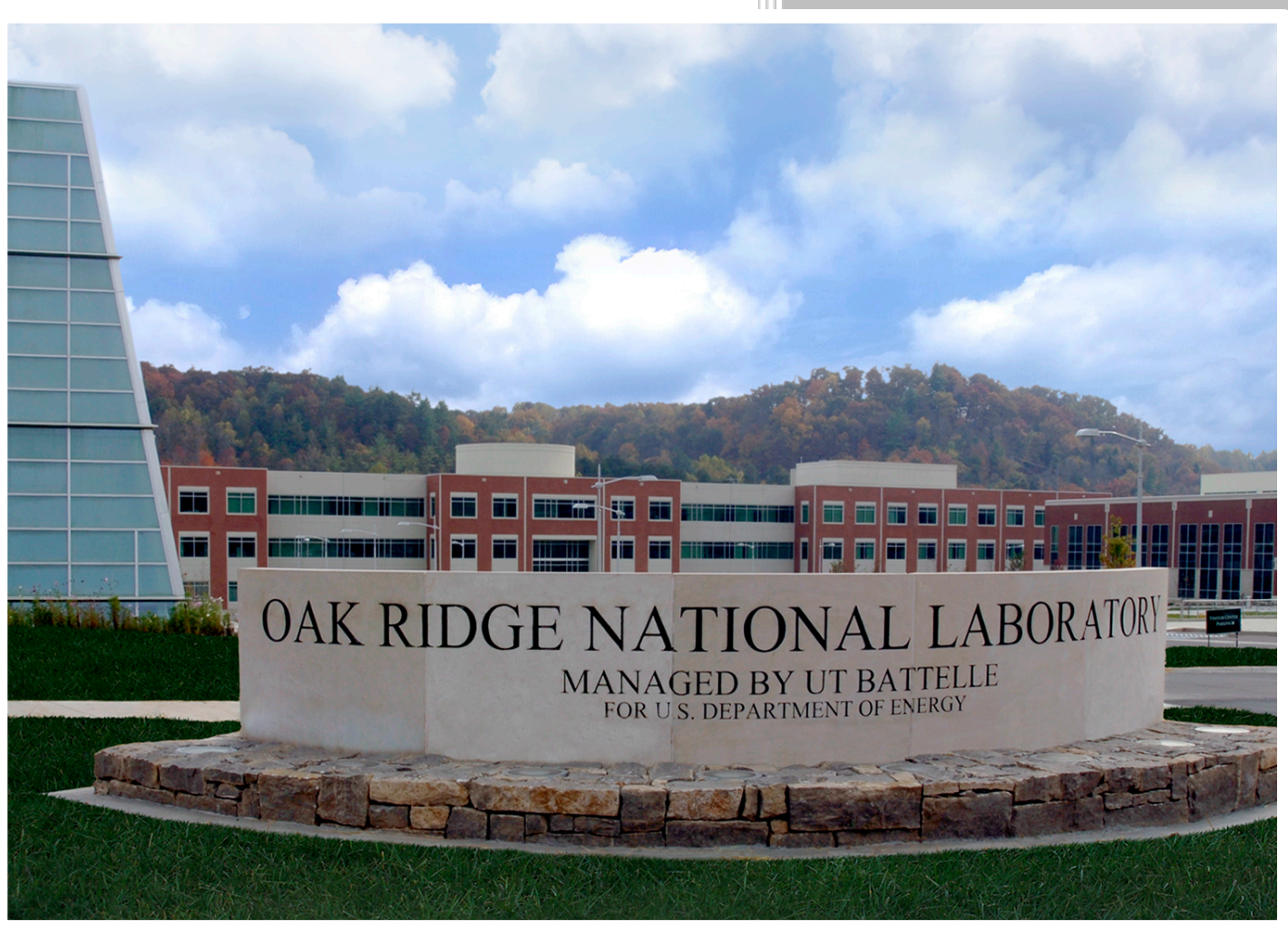

T. R. Watkins

M. J. Lance

L. F. Allard, Jr.

K. Kamasamudram

A. Yezerets

\section{September 2014}




\section{DOCUMENT AVAILABILITY}

Reports produced after January 1, 1996, are generally available free via US Department of Energy (DOE) SciTech Connect.

Website http://www.osti.gov/scitech/

Reports produced before January 1, 1996, may be purchased by members of the public from the following source:

National Technical Information Service

5285 Port Royal Road

Springfield, VA 22161

Telephone 703-605-6000 (1-800-553-6847)

TDD 703-487-4639

Fax 703-605-6900

E-mail info@ntis.gov

Website http://www.ntis.gov/help/ordermethods.aspx

Reports are available to DOE employees, DOE contractors, Energy Technology Data Exchange representatives, and International Nuclear Information System representatives from the following source:

Office of Scientific and Technical Information

PO Box 62

Oak Ridge, TN 37831

Telephone 865-576-8401

Fax 865-576-5728

E-mail reports@osti.gov

Website http://www.osti.gov/contact.html

This report was prepared as an account of work sponsored by an agency of the United States Government. Neither the United States Government nor any agency thereof, nor any of their employees, makes any warranty, express or implied, or assumes any legal liability or responsibility for the accuracy, completeness, or usefulness of any information, apparatus, product, or process disclosed, or represents that its use would not infringe privately owned rights. Reference herein to any specific commercial product, process, or service by trade name, trademark, manufacturer, or otherwise, does not necessarily constitute or imply its endorsement, recommendation, or favoring by the United States Government or any agency thereof. The views and opinions of authors expressed herein do not necessarily state or reflect those of the United States Government or any agency thereof. 
Materials Science and Technology Division

CRADA Final Report

for

CRADA Number ORNL-02-0659

\section{Catalyst Characterization}

T. R. Watkins, M. J. Lance, and L. F. Allard, Jr. Materials Science and Technology Division Oak Ridge National Laboratory

Oak Ridge, TN 37831

K. Kamasamudram and A. Yezerets

Cummins Inc.

1900 McKinley Ave.

Columbus, IN 47201

Date Published: September 2014

Prepared by

OAK RIDGE NATIONAL LABORATORY

Oak Ridge, Tennessee 37831-6283

managed by

UT-BATTELLE, LLC

for the

US DEPARTMENT OF ENERGY

under contract DE-AC05-00OR22725

Approved For Public Release. 



\section{CONTENTS}

Page

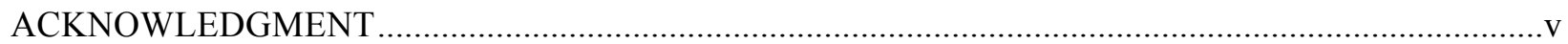

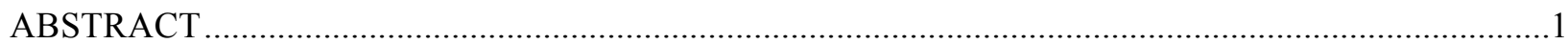

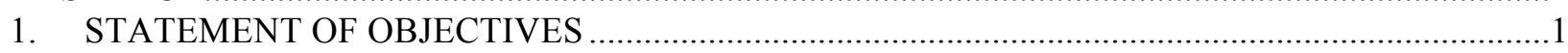

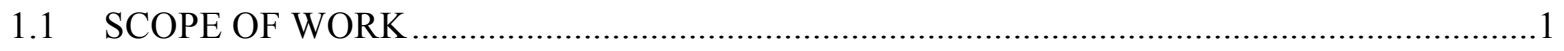

1.1.1 Task 1 (FY02-FY03). Desulfation study to meet 2007 emission regulations .................1

1.1.2 Task 2 (FY04-FY06). Evaluate $\mathrm{NO}_{\mathrm{x}}$ adsorber catalysts to meet 2007 emission regulations

1.1.3 Task 3 (FY07-FY09). Hydrothermal degradation of Fe-Zeolites to meet 2010 emission regulations.

1.1.4 Task 4 (FY10-FY14). Hydrothermal aging of Fe-and Cu-Zeolites to meet 2014 emission regulations

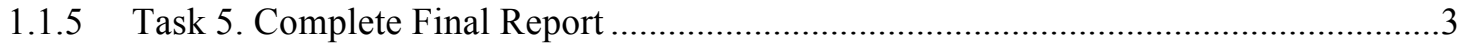

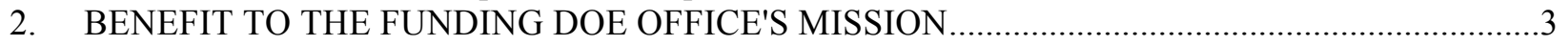

3. TECHNICAL DISCUSSION OF WORK PERFORMED BY ALL PARTIES ….............................

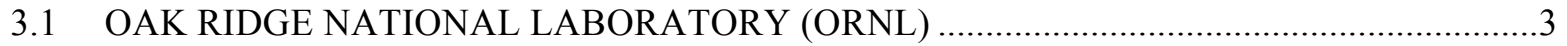

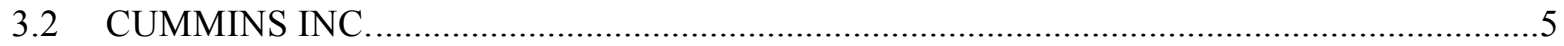

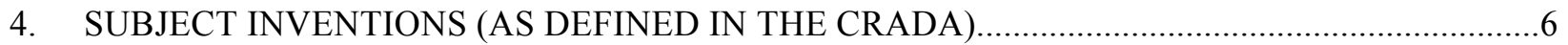

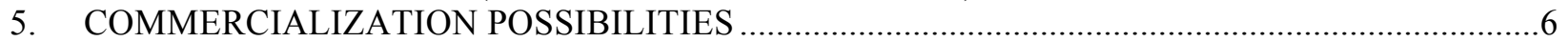

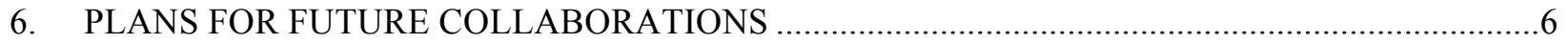

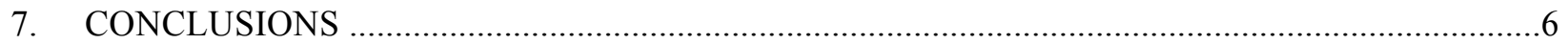

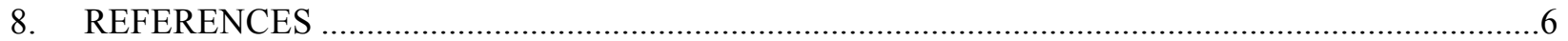

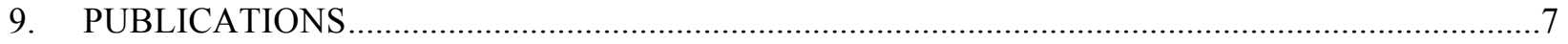





\section{ACKNOWLEDGMENT}

ORNL's contribution to this research sponsored by the U.S. Department of Energy, Assistant Secretary for Energy Efficiency and Renewable Energy, Office of Vehicle Technologies, as part of the Propulsion Materials Program, under contract DE-AC05-00OR22725 with UT-Battelle, LLC. Also, portions of this research utilized equipment purchased through the Oak Ridge National Laboratory's High Temperature Materials Laboratory User Program was sponsored by the U. S. Department of Energy, Office of Energy Efficiency and Renewable Energy, Vehicle Technologies Program.

The authors thank the following for their support and contributions to this project over its lifetime: US DOE's J. Gibbs, S. Diamond; ORNL's A. Haynes, D. Stinton, D. Johnson, H. Meyer, C. Narula, D. Blom, S. Trent, D. Coffey, and R. Meisner; and Cummins' R. D. England, H. Fang, T. Yonushonis and P. Becker. 



\begin{abstract}
A substantial amount of testing and analysis was performed over the 12-year-duration of this Cooperative Research and Development Agreement (CRADA) between Cummins Inc. and the Oak Ridge National Laboratory (ORNL). ORNL's work focused on developing fundamental understanding of the working principles of the selected catalyst technologies to further the development of diesel aftertreatment catalysts . Characterization conducted at ORNL aided Cummins in the understanding of the catalyst working principles and aided in meeting emission regulations for their 2007, 2010 and 2014 year engines, and by extension all diesel engine manufacturers to achieve DOE's goal of improved fuel efficiency and reduced emissions. Diesel oxidation catalysts (DOC), ammonium oxidation catalysts (AMOx), and selective catalyst reduction (SCR) catalysts were characterized during the course of this project. Materials of varying aging history prepared both at ORNL and Cummins under well controlled environments, in a manner that simulated operation under on-road conditions were thoroughly evaluated with advanced characterization and reactor performance evaluation tools. Results generated helped to identify material degradation[ mechanisms (i.e., hydrothermal aging/dealumination of SCR catalysts and Pt grain growth in DOC catalysts) that limit the long-term effectiveness of catalytic devices and suggested possible ways to mitigate catalyst aging.
\end{abstract}

\title{
1. STATEMENT OF OBJECTIVES
}

The global objective of this CRADA was to produce a quantitative understanding of the process/product interdependence leading to catalyst systems with improved final product quality, resulting in diesel emission levels that meet the prevailing emission requirements. Cummins provided catalyst samples that were being considering for use in the next generation of diesel truck systems and for this effort, ORNL provided a supportive role in their continued refinement. This work will ultimately contribute to the achievement of improved efficiency and reduced emissions in advanced combustion engines for our nation's passenger and commercial vehicle applications through accelerated development of costcompetitive advanced catalysts for vehicle applications and new or early stage enabling technologies needed to improve fuel efficiency, performance, and emissions in internal combustion engines.

ORNL was uniquely equipped to partner with Cummins in the experimental evaluation of diesel catalyst systems. ORNL possesses a long history microstructural, crystallographic and chemical characterization of catalyst materials. Unique facilities for catalyst characterization at ORNL include high temperature Xray diffraction (XRD), Raman and Fourier transform infrared (FTIR) spectroscopy and x-ray photoelectron spectroscopy (XPS). Most useful is our aberration corrected electron microscope (ACEM) which has the unique capability of imaging catalysts with sub-nanometer resolution at elevated temperatures and in different environments. All of these capabilities were utilized in this CRADA.

The entire length of the CRADA was 150 months. It began in June 2002 and ended in September 2014. All the tasks are described in the following.

\subsection{SCOPE OF WORK}

\subsubsection{Task 1 (FY02-FY03). Desulfation study to meet 2007 emission regulations}

Develop advanced characterization techniques and establish baseline characterizations of materials from various stages of the catalyst's lifecycle. Verify the location and dispersion of the active elements within the washcoat of a catalyst and determine the temperature dependence and thermal stability of adsorbed $\mathrm{NO}_{\mathrm{x}}$ and $\mathrm{SO}_{\mathrm{x}}$ species. 
Support continued characterizations of state of the art catalysts from various stages of the catalyst's lifecycle. Identify surface adsorbing species during nitration and sulfation via Raman spectroscopy. Perform microstructural, microchemical and crystallographic study of these new materials in simulated engine environments using an ex-situ reactor system with transmission electron microscopy (TEM) and with the HTK 900 stage for use with XRD.

\subsubsection{Task 2 (FY04-FY06). Evaluate $\mathrm{NO}_{\mathrm{x}}$ adsorber catalysts to meet 2007 emission regulations}

Fundamental characterizations of new materials from various stages of the catalyst's lifecycle was continued from the previous years. Obtain rates of desulfation and activation energies for various catalytic compositions after different periods of aging using in situ Raman microscopy. Continue ex situ microstructural, microchemical and crystallographic studies of these new materials in simulated engine environments.

Evaluate the gradient formation on a macro scale of active elements on a catalyst as a function of catalyst history and operating conditions.

Evaluate the thermal degradation of a NOx storage and reduction (NSR) catalyst within the catalyst support brick as a function of macroscopic position, catalyst history and operating conditions

\subsubsection{Task 3 (FY07-FY09). Hydrothermal degradation of Fe-Zeolites to meet 2010 emission regulations}

Evaluate the degradation of a commercial zeolite urea SCR catalysts and a model catalyst as a function of operating conditions (temperature, atmosphere, time) in preparation for accelerated aging work.

Complete evaluation of feasibility of the advanced tools available at ORNL for quantitative analysis of the zeolite based material changes underlying the SCR catalyst performance degradation with age.

\subsubsection{Task 4 (FY10-FY14). Hydrothermal aging of Fe-and Cu-Zeolites to meet 2014 emission regulations}

Initiate evaluation of feasibility of the advanced tools available at ORNL for quantitative analysis of the materials changes underlying the AMOX catalyst performance degradation with age.

Continue ammonia oxidation (AMOx) catalyst characterization of a practically-relevant state of the art zeolite catalyst subjected to hydrothermal aging for lifetime prediction model input.

Begin in situ ammonia oxidation (AMOX) catalyst characterization of a practically-relevant zeolite catalyst subjected to hydrothermal aging at elevated temperatures for lifetime prediction model input using $\mathrm{x}$-ray diffraction or piezospectroscopy

Identify different phases present in as received and $550^{\circ} \mathrm{C} 4 \mathrm{~h}$ hydrothermally treated Cu-zeolite catalyst such as zeolite crystallite and copper oxide phases through, but not limited to, in situ X-ray diffraction and advanced microscopic techniques. Quantify the impact of hydrothermal aging temperature and time on $\mathrm{Cu}$-zeolite crystallite degradation through copper sintering and dealumination process and the spatial distribution of copper species using in situ XRD and microscopy techniques. Quantify the impact of hydrothermal treatment up on platinum crystallite size and distribution in ammonia oxidation catalyst washcoat through microscopy and X-ray diffraction techniques. Correlate the fundamental degradation mechanisms identified by ORNL with activity and selectivity in ammonia oxidation (evaluated at Cummins) on select hydrothermally treated ammonia oxidation catalysts 


\subsubsection{Task 5. Complete Final Report}

The final report will be finished and distributed before the CRADA is officially complete.

\section{BENEFIT TO THE FUNDING DOE OFFICE'S MISSION}

This work was part of the EERE Vehicle Technologies Program and was specifically referenced as an $R \& D$ agreement in the Propulsion Materials subprogram. The subject agreement will leverage DOE funds via the in-kind contributions of Cummins and will provide a path for the commercialization of technologies developed. This, by extension, benefits all diesel engine manufacturers to achieve DOE's goal of improved fuel efficiency and reduced emissions.

The benefit to the DOE Office of Energy Efficiency and Renewable Energy (EERE) Office of Vehicle Technologies (VT) is that it will enable VT to meet it's mission relative to working in partnership with the domestic transportation industry to develop and promote user acceptance of advanced transportation vehicles and alternative fuel technologies which will reduce criteria pollutant emissions and greenhouse gases AND to developing a strong transportation technology base to enable this industry to assure strong competition in the domestic and world markets. The benefit to the DOE VT Office of Propulsion Materials (OPM) is that it will enable OPM to meet it's mission relative to working with industry partners and their suppliers to research and develop technologies that make heavy vehicles more energy efficient and able to use alternative fuels, while reducing vehicle emissions. The benefits to the ORNL are related to performance of their mission in enabling and development of new energy efficient technologies of great interest to industry.

\section{TECHNICAL DISCUSSION OF WORK PERFORMED BY ALL PARTIES}

\subsection{OAK RIDGE NATIONAL LABORATORY (ORNL)}

To assist the diesel engine community and to help achieve DOE's goal of improved fuel efficiency and reduced emissions, ORNL provided technical R\&D support to Cummins involving Cummins' provided state of the art and advanced catalysts materials through the above-listed Tasks. Different catalysts systems were evaluated over the 150-month-long project and their complete reporting to Cummins may be found in references 1 and 2. Sensitive Cummins information and materials were supplied to ORNL, and the executed Non-Disclosure Agreement and the executed Material Transfer Agreement to protect those are attached in Appendices M-N.

The following is a brief synopsis of work conducted during the project's 150 months, and overviewed in references 1 and 2 .

FY02 (October 2001 - September 2002):

The baseline characterizations of materials from various stages of the catalyst's lifecycle were accomplished. The location and dispersion of active elements within the catalyst were determined.

FY03 (October 2002 - September 2003):

All techniques (XRD, microscopy and spectroscopy) were shown to be very useful in monitoring Pt changes in size and location within these catalytic samples. The observed increase in the Pt particle size, although significant, was still comparable to that observed in commercial three-way catalysts for gasoline 
engines. While Raman spectroscopy could not directly measure the Pt particle size in these samples, the changes in the catalyst support spectra with Pt size were calibrated for this specific catalyst formulation and were used for measuring Pt particle coarsening. Raman and XPS techniques showed promise for future in-situ desulfation work and chemical state identification of surface species, respectively.

\section{FY04 (October 2003 - September 2004):}

Supported continued characterizations of new materials from various stages of the catalyst's lifecycle. Obtained rates of desulfation and activation energies for various catalytic compositions after different periods of aging. Continued ex-situ microstructural, microchemical and crystallographic studies of these new materials in simulated engine environments.

\section{FY05 (October 2004 - September 2005):}

Evaluation of gradient formation on a macro scale of active elements on a catalyst as a function of catalyst history and operating conditions. Supported continued characterizations of new materials from various stages of the catalyst's lifecycle. Began determination of the soot and ash distribution as a function of macroscopic position within the NSR catalyst support brick.

\section{FY06 (October 2005 - September 2006):}

Supported continued characterizations of new materials from various stages of the catalyst's lifecycle. Xray diffraction, X-ray photoelectron Spectroscopy and Scanning Transmission Electron Microscopy were used to evaluate the thermal degradation of a NOx storage and reduction (NSR) catalyst within the catalyst support brick as a function of macroscopic position, catalyst history and operating conditions. Completed two studies characterizing a new catalyst system and a diesel oxidation catalyst in the unused and aged states.

\section{FY07 (October 2006 - September 2007):}

The evaluation of degradation of a commercial zeolite urea SCR catalysts and a model catalyst as a function of operating conditions defined by the end user has been completed. Supported continued characterizations of new materials from various stages of the catalyst's life cycle.

\section{FY08 (October 2007 - September 2008):}

XRD, TEM, DRIFTS, NMR and XPS all showed the effect of hydrothermal aging after $900^{\circ} \mathrm{C}$ exposure. XRD indicated that the degree of crystallinity is decreasing. Dealuminization was observed with NMR, DRIFTS and XPS. TEM shows $900^{\circ} \mathrm{C}$ hydrothermally aged sample is more stable under electron beam relative to as-received sample.

\section{FY09 (October 2008 - September 2009):}

Based on the FY2008 and FY2009 work, XRD, TEM, DRIFTS, NMR and XPS all showed the effect of hydrothermal aging after $900^{\circ} \mathrm{C}$ exposure. Dealuminization was observed with NMR, DRIFTS and XPS as hydrothermal aging temperature increased. Spectroscopic techniques and NMR provide important information about hydrothermal degradation of Fe-zeolites. In contrast, XRD and TEM do not provide enough insight into the early stages of the hydrothermal aging process. 


\section{FY10 (October 2009 - September 2010):}

The as-received AMOx catalyst was characterized using XRD, TEM and XPS. Redesigned and improved portable gas manifold system. This system provides varied atmospheres for in situ studies using diffraction, spectroscopy, and microscopy.

\section{FY11 (October 2010 - September 2011):}

The as-received AMOx catalyst was characterized using XRD, FTIR, XPS and TEM. The effect of hydrothermal conditions on the AMOx catalyst appeared to increase order and crystallinity in the FeZeolite (FTIR+XRD). XPS indicated that the surface was slightly depleted in Fe. The Pt particles size increased from 3 to $20 \mu \mathrm{m}$ from 0 to $10 \mathrm{hrs}$. at $650^{\circ} \mathrm{C}$ in simulated air with $7 \% \mathrm{H}_{2} \mathrm{O}$. Hydrothermal aging studies will continue to evaluate the feasibility of the advanced tools available at ORNL for quantitative analysis of the materials changes underlying the AMOx catalyst performance degradation with age.

\section{FY12 (October 2011 - September 2012):}

AMOx and SCR catalysts (SCR formulation is integral part of AMOx technology and plays a critical role in controlling selectivity) have been characterized. For the AMOx catalysts, the XRD patterns for all the hydrothermal aging temperatures were very similar. This suggests the material aged quite quickly above $600^{\circ} \mathrm{C}$ in simulated air with $7 \% \mathrm{H}_{2} \mathrm{O}$. The primary observation was that the catalyst comprises a two-layer system, with a Pt/ $\mathrm{Al}_{2} \mathrm{Ox}$-based inner layer and a zeolite particle outer layer. In the sample hydrothermally aged at $600^{\circ} \mathrm{C}$ (both 1 and $2 \mathrm{hr}$ ) in $7 \% \mathrm{H}_{2} \mathrm{O}$, the Pt particles range in size from $15 \mathrm{~nm}$ at the largest down to smaller than $1 \mathrm{~nm}$, and there existed a dispersion of disordered rafts of atoms. Also single atom species were observed over the surfaces of the alumina support. However, after a $900^{\circ} \mathrm{C}$ hydrothermal aging temperature, no similar atoms and clusters or rafts were seen, and the Pt particles were much larger and more widely dispersed.

\section{FY13 (October 2012 - September 2013):}

The overlapping $\mathrm{NH}_{3}$ storage and oxidation functions, observed in one of the $\mathrm{Cu}-\mathrm{CHA}$ formulations, can potentially reduce $\mathrm{NH}_{3}$ slip from the $\mathrm{SCR}$ catalyst. At least two distinct $\mathrm{NH}_{3}$ storage sites were present in the $\mathrm{Cu}$-CHA formulation. Progressive hydrothermal treatment at $600^{\circ} \mathrm{C}$ leads to a redistribution of the $\mathrm{NH}_{3}$ storage sites, wherein the weak storage site increase at the expense of the strong storage sites. With careful sample preparations, elemental $\mathrm{Cu}$ can be mapped in a chabazite particle.

\section{FY14 (October 2013 - September 2014):}

Additional samples were characterized using in-situ high temperature XRD with the portable gas manifold system and ACEM. ${ }^{4}$ The final report was written.

\subsection{Cummins, Inc.}

Cummins' technical role was to provide state of the art and advanced catalyst technologies whose fundamental working principles are not well understood and also provide in kind support by evaluating the performance of these technologies at their facilities. Cummins developed performance evaluation and aging criteria for these samples and had been aged at Cummins following procedures designed to simulate engine operation. Cummins also provided equipment used for the construction of the portable gas manifold system. Periodic teleconferences and meetings were conducted and information and test results were exchanged. Cummins supplied information from their parametric bench-top reactor studies as well as their engine test cell studies. 


\section{SUBJECT INVENTIONS (AS DEFINED IN THE CRADA)}

"Subject Invention" means any invention of the Contractor (UT-Battelle, LLC) or Participant (Cummins, Inc.) conceived or first actually reduced to practice in the performance of work under this CRADA.

There were no inventions conceived or first reduced to practice as a consequence of the completion of this project's work.

\section{COMMERCIALIZATION POSSIBILITIES}

Results from this CRADA and other CRADAs at ORNL were put into the 2007 Dodge Ram pickup truck. ${ }^{3}$ Subsequent results were applied as well. For the greater diesel engine community as a whole, there are a few ways in which the work performed during this CRADA may have commercial impact. The observation of changes in catalyst nanostructure following hydrothermal aging provide insight into better catalyst design that would prevent segregation of catalytically-active species out of the zeolite structure. Also, analytical techniques partially developed through this CRADA (i.e., environmental testing in the ACEM) may be commercialized in the future.

\section{PLANS FOR FUTURE COLLABORATIONS}

Should follow-on work be pursued by Cummins, Inc., then there is a likelihood that ORNL will continue to provide support to Cummins.

\section{CONCLUSIONS}

The microstructural, chemical and crystallographic characterization techniques developed and performed by ORNL, in combination with the performance analysis helped Cummins, Inc. to gain fundamental insights in to various catalyst technologies working principles and guided catalyst aging and controls strategies and also refine their catalyst compositions thus improving the thermal stability and efficiencies of those materials.

\section{REFERENCES}

1. http://energy.gov/eere/vehicles/vehicle-technologies-office-annual-progress-reports

2. PTS entry \# XXXXXX: T. R. Watkins, M. J. Lance, L. F. Allard, Jr., K. Kamasamudram and A. Yezerets, ORNL/TM-2014/ORNL-02-0659A, CRADA Final Report for CRADA Number ORNL-020659 with Appendices, Catalyst Characterization, October 2014.

3. Letter from John Wall, VP \& CTO, Cummins Inc. to Thomas Watkins, February 15, 2007.

4. K. Kamasamudram, A. Kumar, J. Luo, N. Currier, A. Yezerets, T. Watkins and L. Allard, "New Insights into the Unique Operation of Small Pore Cu-Zeolite SCR Catalyst: Overlapping NH3 Desorption and Oxidation Characteristics for Minimizing Undesired Products," SAE Technical Paper 2014-01-1542, 2014, doi:10.4271/2014-01-1542. 


\section{PUBLICATIONS}

The following is the list of publications related to this CRADA:

1. K. Kamasamudram, A. Kumar, J. Luo, N. Currier, A. Yezerets, T. Watkins and L. Allard, "New Insights into the Unique Operation of Small Pore Cu-Zeolite SCR Catalyst: Overlapping $\mathrm{NH}_{3}$ Desorption and Oxidation Characteristics for Minimizing Undesired Products," SAE Technical Paper 2014-01-1542, 2014, doi:10.4271/2014-01-1542.

2. H. L. Fang and M. J. Lance, "Influence of Soot Surface Changes on DPF Regeneration," SAE Paper no. 2004-01-3043 (2004).

3. R. D. England, H. Fang, T. R. Watkins, M. Lance and D. Blom, "X-ray Diffraction and Vibrational Spectroscopy of Catalysts for Exhaust Aftertreatment," pp. 139-145 in Advances in X-Ray Analysis, V45. Edited by T. C. Huang et al., ICDD, Newtown Square, PA, 2002. 
